\title{
PROLOGUE: HISTORY OF THE TIV
}

\author{
Harold M. Bergsma
}

At the outset, it should be stated that Rupert East's own 'Introduction' to his Akiga's Story, which was first published in 1939 by Oxford University Press for the International African Institute, provided a balanced account of Akiga Sai's emergence as a remarkable African and Tiv intellectual whose achievements were amazing for many reasons. East writes: 'Other books have been written by Africans about the life of their own people, though not yet in Northern Nigeria. Others will be written, but they will be written by more sophisticated authors who have the advantage, or disadvantage, of a modern education, whose outlook is no longer primitive and whose knowledge is no longer subjective. Only a man such as Akiga can act as the mouthpiece of the elders and of the older order.'

During the lengthy process of translating and editing the entire Tiv manuscript, called History of the Tiv, one concept which East used constantly came to mind. East stated that Akiga acted as a mouthpiece of the elders. The task of the translator is to give respect and credence to that role so that this English translation of the entire manuscript does in fact speak for Akiga and become his mouthpiece. No section of the Tiv manuscript was omitted, and the order of the material was left as Akiga wrote it in Tiv. This translation of his history contains all of its elements the clans, genealogies, plant and animal names, food preparation, marriage customs and the religious practices of the Tiv - all of which Akiga considered to be of value. Atah Pine, a Tiv scholar and author, wrote recently: 'He bestrides both anthropology and history like a colossus and it is this feat that illuminates his magnificent halo on Tiv and contemporary African Studies.' ${ }^{1}$ Translators of this work were Tiv intellectuals who worked as members of a team, volunteers who took the time to honour Akiga Sai by translating carefully all of Akiga's words, without omission, into modern English usage. Their names are listed in the supplementary materials available online at Appendix 1.

\footnotetext{
HAROLD BERGSMA has a PhD from Michigan State University, in International and Comparative Education with cognates in African Anthropology and Linguistics. He is a fellow of the African Studies Center, Michigan State University, and Emeritus Professor of Curriculum and Instruction, New Mexico State University. Bergsma worked among the Tiv for twelve years (1955-67) in institution development projects. He was the Founding Principal of the W. M. Bristow Secondary School in Gboko, as well as Founding Principal of the Combined Secondary School in Takum, Nigeria. During his tenure in Tivland, he spent considerable time among the traditional Tiv studying their religious practices. His collections of religious artefacts, including a large collection of Ijembe i Aôndo (stone 'axes of God') as well as a collection of other artefacts relating to traditional religious practices, were all donated to the Jos Museum. He and Ezekiel Akiga, a son of Akiga Sai, deposited the original manuscript of History of the Tiv in Ibadan University library in September 1964. He is the chief project editor and translator of History of the Tiv. Martin Akiga, a grandson of Benjamin Akiga Sai, played the role of translation project manager and assistant editor to this article author. Email: bergsma@cox.net; mlakiga@yahoo.com

${ }^{1}$ Atah Pine, 'Akiga Sai: anthropologist or historian? Notes toward an epistemological identity', $<$ https://www.academia.edu/2973665/AKIGA_SAI_ANTHROPOLOGIST_OR_HISTORIAN_ NOTES_TOWARDS_AN_EPISTEMOLOGICAL_IDENTITY>, accessed 2 August 2015.
}

(C) International African Institute 2015 
What was truly remarkable about this new translation was that it was performed by native bilingual Tiv speakers, intellectuals from many walks of life in the Tiv diaspora, and at home, who 'listened' to Akiga's voice as they read the Tiv manuscript and transformed this into English, thus becoming his mouthpiece. Tiv is a tonal language. They listened in the sense that the printed words evoked intonations with meanings for them, which would only be the case with native Tiv translators.

The translators' usages of English words reflect their own lives and wealth of bicultural experience. No two translators would create exactly the same rendering of meanings, simply because of who they are. Does one, for instance, use the word $l a d y$ or woman for the Tiv word kwase? Does the translator avoid explicit sexual references used by Akiga and write 'a private act', or 'married her', or 'flirt', 'cater to' instead of 'sexual intercourse'? Does the Tiv word $g a$ imply negation or not, or does it indicate what we would call a question mark at the end of a sentence with tonal change? Additionally, the editorial efforts are coloured by the editor himself. The editor's cosmological orientation affects his viewpoint. Does a portion of the translated text reflect the philosophical or religious bias of the translator? Of course the answer is yes. In other words, translation and editing are by their very nature existential and somewhat subjective processes.

Editing these translations into one unit, one history, was challenging for a number of reasons. There was the need to combine a number of 'voices' into a unified whole that was harmonious and balanced. Editing required the creation of an original 'score', to use a musical analogy, for the Tiv manuscript, which was a constant editorial companion, so that the voices of the 'octet' translation team blended well without omission.

The presence of a 'Tiv team' was implied above. It is important to reinforce this concept. Team players bring a wealth to translation that would not occur if a single individual were involved, were he a Tiv or a qualified expatriate. Thus, a few words are necessary about the short history of how this translation occurred. It is an interesting history.

In 1964, the writer was Principal of the W. M. Bristow Secondary School in Gboko, Nigeria. A Tiv worker who was cleaning a warehouse room at Mkar, dusting, sweeping, and throwing away old boxes and trash, came across a dusty old document, the cover of which was being eaten by termites. He set it aside. Later, when he was working for me doing yard work, he brought the document and asked if it should be thrown away with the other trash. I opened the first page and read in Tiv: 'Hi sha iyange $i$ m hi veren ishuma sha u me nger takerada ne yo, nyian yena anyom ikundu kpeghe tso.' Translated into English, this meant: 'It was almost twenty years ago when I first contemplated writing this book.' The next page was more amazing. It was a torn cover sheet, hand printed, which stated 'AKIGA'S HISTORY', and underneath this, in cursive script in ink, was written 'History of Tiv By Akiga'. But this is just the beginning of this story.

One of the teaching staff members at the secondary school of which I was administrator was a man called Ezekiel Akiga! I met with him, manuscript in hand, and asked him if he knew about the work, or if he had read it. He replied that he had heard about it, and that the family, perhaps one of Akiga's sons, might still have had a copy, but he was not sure about that.

After some discussion, Ezekiel A. Akiga and I agreed that such an old treasure must not be lost or destroyed and that it should be archived in a safe place. I 
suggested that it could be archived in a university, perhaps at that time the most prestigious one, the University of Ibadan in Nigeria. I had been involved with writing about the Tiv religion and Tiv proverbs and had made contact with Professor Robert G. Armstrong at the University of Ibadan. I contacted Professor Armstrong, who then visited us at the school in Gboko. We talked about Rupert East's edition of portions of Akiga's text, published by Oxford University Press for the International African Institute as Akiga's Story. Armstrong took the old manuscript, and later, when he travelled north into the Benue Province, hand-delivered two duplicates. I have that very document in front of me now, on my lap, one of two copies of the original manuscript, and I read:

\section{UNIVERSITY OF IBADAN, NIGERIA, INSTITUTE OF AFRICAN STUDIES}

Certificate This is to certify that Mr. Harold Bergsma, in the presence of Mr E. A. Akiga, has deposited with Professor R. G. Armstrong an original Tiv manuscript of Akiga's story. It is understood that Professor Armstrong is to deposit this manuscript with the library of the University of Ibadan for archiving and reproduction by microfilm and Xerox. The manuscript will remain the property of the Akiga family according to an agreement to be drawn up which must be satisfactory to the family and the University library.

Signed by: Harold M. Bergsma, Robert G. Armstrong and Mr Ezekiel A. Akiga. April $28^{\text {th }} 1964$

That manuscript may have been completed in Tiv by Akiga by 1935, and part of it was translated and published in English in 1939. From time to time I have taken the old manuscript from the shelf while researching and writing about the Tiv. It is accompanied by a number of other Tiv documents, most dating back to the early 1940s.

What happened between 1964 and 2014 with my copy of Akiga's document in Tiv is that it rested in my library, and its twin copy was with the now late Ezekiel Akiga. More than three years ago I picked up the Tiv manuscript, which was next to the published work of Rupert East, Akiga's Story. I read them both again carefully and was struck by the fact that nearly half of the manuscript's contents had never been translated or published.

I researched the web for members of Akiga Sai's family and was happy to locate Martin Akiga, a grandson, who lived in England. Martin became the facilitator for the next part of this project: that is, he contacted a number of professionals in the Tiv diaspora and in Nigeria, and eleven of them agreed to translate sections of the manuscript. I made a Xerox copy of the material I had, mailed the heavy parcel to Martin Akiga in England, and over a two-year period all the segments of this important historical work were translated, integrated into one document, edited and submitted to the IAI, the same organization that had published Rupert East's work so many years ago.

Who was this man Akiga? When did he live? How did he happen to write a history about his people?

Akiga himself tells the story about his childhood, his family, and his early experiences with akombo and witchcraft. The first chapter of this Tiv manuscript 
is most interesting reading, and brings a smile to one's lips, reflecting Akiga's own joy in writing about how he came to write this Tiv history and how he researched it in the geographical area we called Benue Province.

It is hard for me to imagine what Tivland was like in 1898, approximately the time of Akiga's birth. My excursions into the 'bush' areas of Tivland over a twelve-year period ended in 1967, so I went back to review materials and pictures of the late 1950s and looked over the Polaroid snapshots in my albums of village communities. I once again saw individual people I had known, some with scarred faces, women with beautifully scarred abdomens, pictures of those with crippling illness that afflicted the people during that time and left many unable to farm or work. I remembered those with blindness from trachoma and elephantiasis, and cerebral malaria - conditions that were all too common. I visited many villages in which there were only a couple of people who could read, where entire age sets of children had never seen a school, and many villages where the children were seeing a Whiteman for the first time! Polygamy was the norm at that time, and early marriages with very young girls were common. Hospitality! That memory comes back strongly. Without exception, in every remote village I visited I was treated as a guest with honour and hospitality. People shared their food. Drumming and dancing! There are still so many vivid, pleasant memories of Tivland.

I recalled that there was fighting and bloodshed in the mid-1960s as the Tiv attempted to create a separate region and were blocked by the northern Muslim-based political parties. 'Tarkaa!' Out of much turmoil came the creation of the Benue-Plateau State in 1967. The Tiv now had a homeland. That was my experience. What was this part of Nigeria like during the much earlier period of Akiga Sai's life as a historian?

As Akiga began research for his book in the early 1930s, Nigeria was still a colonial entity of the British Empire. District Officers and Residents carried out their duties and ruled the country. Akiga describes this era so well in 'Coming of the Whiteman', the colonial rulers who exerted their authority to stamp out 'cannibalism' and witchcraft. Akiga Sai's father, Sai Dekpe, was, according to Atah Pine, a 'pathological polygamist'. ${ }^{2}$ Akiga himself was also a polygamist later on in life. One of his wives, who bore nine children, was a woman who had been a free slave girl of Kanuri extraction. She was converted to Christianity from Islam by the missionaries and that is how Akiga met her.

Yet Akiga, who was given as a houseboy to a missionary, Reverend Zimmerman, learned to read and became a Tiv translator for missionaries who were preaching in Hausa at that time. According to E. N. Casaleggio, Akiga was the very first Tiv person to write in the Tiv language. In his book The Land Will Yield its Fruits: fifty years in the Sudan (1965), there is a letter of appreciation to the missionaries that Casaleggio recorded was written by young Akiga in 1914 . 'Mo su we sha u chi u ka se kwagh Aôndo. Asuma ase do kpishi, u ungwa de?', meaning 'I thank you because you told us the thing of God. Our hearts are good, do you hear?' (for the continuation of this citation, see Fardon, this issue, p. 591).

\footnotetext{
${ }^{2}$ See Atah Pine, 'Akiga Sai, 1898-1969: a Tiv historiographer and his craft', <https://www. academia.edu/879829/Akiga_Sai_1898-1959_A_Tiv_Historiographer_and_His_Craft>, accessed 2 August 2015.
} 
Akiga emerged from a traditional culture, ruled by colonial masters. He was influenced by missionaries who were beginning to establish schools and bring Christianity, and became literate and a Christian. He mentioned that Tiv culture was on the verge of extinction. If that was the case in the mid-1930s, one wonders what has become of it now. However, since his history was written at a time when traditional Tiv practices and language were extant, this complete version of his work becomes a valuable marker for future studies.

It has been mentioned that this work is a translation of the entire manuscript written by Akiga Sai. To the eleven members of the translation team, this meant that their task was to write a portion of the manuscript in the English language directly from the Tiv words that Akiga wrote so long ago. They have achieved their task well. Editorial comments have been kept to a minimum in the current translation: brief glosses have been inserted into the text in square brackets, and occasional comments and explanations provided in footnotes.

One problem for both translators and editors relates to the host of Tiv names and concepts used by Akiga when he wrote this history. Let me emphasize it here: in this work, most proper nouns in Tiv, and there are hundreds, are left as they were written; most of the names for places were left as Akiga wrote them; and all the names of clans, rites and ceremonies were not changed, and in most cases were not translated. A few insertions within the text were made, particularly for names of animals and birds. These were inserted in brackets next to the Tiv word, such as 'ati [ground dove]', but the translators did not know the identity or names in English of many of these animals.

Akiga used many plant and animal names, some of them common usages like chicken, snake, guinea fowl, rat and monkey. But he used scores of specific names for special plants and herbs used for medicinal treatments or for divination purposes. Where possible, we have used the actual name of a bird, animal or plant. Language is dynamic and changes over time, and every effort has been made by the translators to provide a translation that is current and meaningful. Tiv spellings vary, as do spellings within the manuscript, and Akiga's renderings remained a challenge. In most cases, dictionaries and reference works do not provide translations, except in a general way, stating, for instance, a 'tall leafy tree' or 'a small bird'. Translators themselves may speak Tiv words differently, some using an ' $r$ ' sound for the ' 1 ' sound: this interchangeability is a common occurrence among Tiv speakers.

There are a number of references made to taxes, spheres of value, trade and currency, including terms such as ikundu, pue ikundu, bashi, kobo and others related to exchange practices. The traditional Tiv did not have money, or standard currency, so the Tiv used many things of value for exchanges and purchases, including payments of bride price and payment of taxes with cows. Among these things of value were woven cloths (ikundu), copper bars (bashi) and other items. Ikundu actually means 'value', but it also means twenty, or it can mean a cloth of twenty woven strips sewn together, or one with ten strips, pue ikundu. These terms can be euphemisms for other meanings. Bashi, for instance, could be used in a sentence to refer to the type of payment made, such as with a cow; if it later becomes ill or crippled, then the recipient complains of a tainted bashi, with ichul, a defect. These usages are understandable if one thinks about how in American culture we say, 'How much dough did you pay for that?', and the reply, 'Oh, nearly ten bucks.' Later on, coinage was introduced by the British Colonial Government: pounds (pam), shillings (sule) and pence (kobo - from 'copper'). Traditional means for 
exchange were gradually abandoned when standard values related to money had been introduced.

The section devoted to the crops of the Tiv is a real botanical-historical treasure. Akiga mentions dozens of plants in various categories, including tuber crops, grain crops, legumes and others, by name and according to how each is to be planted, in what kind of soil and in what season. Not only is this a botanical history but a linguistic treasure because he presents the linguistic derivation of most of the names, including many from other ethnic groups around the Tiv, examples of cultural borrowing. While reading this section, I was particularly interested in the anthropological and social implications of how and by whom crops were to be planted. Many crops required children to participate in pushing down the stalks, men cutting the heads of grain and women processing these.

Moreover, certain crops were the domain of wives in the village, others of men exclusively. Akiga's narrative is much more than just an account of rural agricultural practices, but a history of gender roles related to agriculture, unlike any other traditional people's histories that I have read. Names for locations and social groups, directions to villages, people's names in the hundreds that Akiga used may no longer have the same meaning, yet because he took time to mention the ancestors, and spell out their names, these have now become part of Tiv history. Long sections of this manuscript are oral histories of clans of the Tiv, who begat whom, and how the segments of this ethno-linguistic group of people moved about in the lands near the Benue River and the Katsina Ala River - in fact, as far as to the border of the Cameroons.

No maps are available to show how these groups moved around during Akiga's lifetime. What one gleans, however, is that the Tiv before Akiga's time fought dozens of bloody battles for dominance, land and revenge. This is a history of conflict and great unrest and the settlement of a people geographically. ${ }^{3}$

This translation of the complete work entitled History of the Tiv complements the much earlier partial translation that was published with extensive and illuminating commentaries by Rupert East in Akiga's Story. Akiga's organization of the content into chapters and subsections is preserved; and something approaching an 'unexpurgated text' is presented.

This new complete translation is important for the large, well-educated, international Tiv community, numbering now in the millions, who can read and wonder about their fascinating past, perhaps with the names of some of their relatives, their history, their language and the culture from which they emerged. It gives African studies specialists, language experts, linguists, anthropologists and geographers additional insights into this culture.

Akiga was a traditional man, but also a modern intellectual, a 'colossus' as Pine states above. His history began in the 'bush'. Akiga rose from humble beginnings in an ethnic group and achieved what few men have. He became an editor of a Tiv

\footnotetext{
${ }^{3}$ Rupert East states that during the preparation of his edition of Akiga's book, published as Akiga's Story, there were fifty-two Tiv clans or sub-clans. In addition to major clan names, there are numerous references to sub-clans, kindred and different ethnic groups that lived near or with the Tiv, including the Udam, Utur (Etulo, Itloo), Kuteb, Mambila and Jukun, which in turn had their divisions. The term Uke is used by Akiga for the Hausa and in a general way for other large ethnic groups to the north of the Tiv.
} 
newsletter, Mwanger $u$ Tiv, he became a missionary for a period of time, an administrator, a member of the Northern House of Assembly of Nigeria, a translator, and a historian; and, interestingly, he became a polygamist himself. Truly, he was a public intellectual who emerged like the mushrooms that rise up after the old ones die out.

Akiga's History of the Tiv is an amazing work, perhaps unrivalled among any traditional histories derived from the native language by members of their own societies. Rupert East, in his book Akiga's Story (p. 7), writes his evaluation of Akiga's full manuscript: 'Indeed the whole book is concerned with persons rather than things. This is to be expected, for no normal African could, or would wish to write an impersonal review of contemporary events such as might be demanded from a European historian.' Akiga was an exceptional African intellectual and his writing was most personal when relating to his own situation, and most objective when describing his people's way of life. He was not a trained linguist or anthropologist; however, what he achieved in this historical work will be honoured by many of his own people and by those who study the lives and languages of those in the African world.

Some of my spelling 'disputes' for this manuscript, History of the Tiv, were resolved by reference to the wealth of experience and expertise of those who translated the text. Cultural and linguistic information came from a wealth of sources, listed in the bibliography. ${ }^{4}$

\section{SUPPLEMENTARY MATERIALS}

Supplementary materials, including the full new translation introduced in this prologue and excerpted below, a scanned version of the Tiv original typescript, and associated appendices and references, as listed below, are available with this article at <http://dx.doi.org/10.1017/S0001972015000613>.

- Appendix 1: Team of translators, arranged alphabetically

- Appendix 2: Some of the actors in Akiga Sai's History of the Tiv identified by David Dorward

- Appendix 3: 'The Story of Inyamibuan by B. Akiga', translated and edited by William Burgess

- References cited in the translation and appendices

\section{ABSTRACT}

This article introduces a new translation of Akiga Sai's History of the Tiv, a manuscript completed in Tiv by Akiga in 1935. Portions of Akiga's text, translated and annotated by Rupert East, were first published in English by the International African Institute in 1939 as Akiga's Story. But the new translation, available in

\footnotetext{
${ }^{4}$ One cannot but have great admiration for the ethnographic surveys, maps and dictionaries of early colonial District Officers who were assigned to the Tiv of Nigeria by the British Colonial Government. They remain a treasured source for historians, linguists and geographers.
} 
the online version of the journal, is the first complete one: no section of the Tiv manuscript has been omitted, and the order of the material has been left as originally written by Akiga. This article tells the story of how Harold Bergsma, when working as a secondary school principal in Nigeria, rescued the Tiv typescript from the rubbish bin and deposited it in the University of Ibadan library; and how, some forty-five years later, he assembled a team of Tiv intellectuals to undertake the task of translation. It reflects on some of the linguistic challenges presented by the Tiv text, and draws attention to the rich and varied information the work contains - on clans, genealogies, plant and animal names, food preparation, marriage customs, the religious practices of the Tiv, and Akiga's own experiences of childhood, family, and encounters with akombo and witchcraft. The article is complemented by selections from Chapters 8 and 9 of the new translation, chosen and annotated by Richard Fardon.

\section{RÉSUMÉ}

Cet article présente une nouvelle traduction du manuscrit d'Akiga Sai intitulé History of the Tiv, rédigé en tiv en 1935. Des parties du texte d'Akiga, traduites et annotées par Rupert East, furent publiées pour la première fois en anglais par l'Institut africain international en 1939 sous le titre Akiga's Story. La nouvelle traduction, disponible dans la version en ligne de la revue, est cependant la première qui soit complète: aucune partie du manuscrit tiv n'a été omise et l'ordre du texte est fidèle à l'original rédigé par Akiga. Cet article raconte comment Harold Bergsma, alors qu'il était directeur d'une école secondaire au Nigeria, a sauvé la copie dactylographiée du texte tiv d'une poubelle avant de la remettre à la bibliothèque de l'Université d'Ibadan; et comment, quelque quarante-cinq années plus tard, il a rassemblé une équipe d'intellectuels tiv pour entreprendre la tâche de traduction. Il se penche sur quelques problématiques linguistiques posées par le texte tiv, et attire l'attention sur la richesse et la diversité des informations contenues dans l'ouvrage concernant les clans, les généalogies, les noms de plantes et d'animaux, la préparation de la nourriture, les coutumes du mariage, les pratiques religieuses des Tiv, ainsi que les expériences personnelles d'Akiga de l'enfance, de la famille, des akombo et de la sorcellerie. Des extraits des chapitres 8 et 9 de la nouvelle traduction, choisis et annotés par Richard Fardon, viennent compléter l'article. 


\section{AKIGA SAI: EXCERPTS FROM HISTORY OF THE TIV}

Some excerpts from Chapters 8 and 9 of Akiga's account of the abuses of chiefship preface his narrative of the visit of the chiefs to Kaduna. This is followed by an account of the founding and growth of Makurdi, the most important Tiv town. These excerpts have been selected by Karin Barber and Richard Fardon, who have further provided the editorial notes based on research by David Dorward.

\section{WHITEMAN'S CHIEF}

[...] During the early stage of the coming of the Whiteman, the Tiv did not understand the Whiteman's culture. That being so, they did not like the chiefs to be appointed by the Whiteman. If the white colonial administrator appointed a person to be a chief, the person would reject the offer because the people felt a chief appointed by colonial officers was never regarded as such. The people who were appointed chiefs by the colonial administrators were never respected; people would ask what calibre of chiefs they were, since they always went about under the hot sun adjudicating cases. The people made all sorts of ridiculous comments to insult the chiefs appointed by the white colonial administrators. [...]

The Tiv people did not know about dugwer, the native authority policemen. The elder appointed by the Whiteman for overseeing the kindred group or clan was called buteril or black foreigner by the Tiv people. [...] The chiefs appointed by the Whiteman usually did not do much of the Whiteman's job; they were mostly engaged in extortion. The head soldiers were mostly the ones running errands. It was the same with the tor shoja that used to attend to the Whiteman. At times the tor shoja could not reach the Whiteman - they could only contact his staff, but nevertheless came back to their kindred groups and told them their words were from the Whiteman and frightened them. [...]

\section{CHIEFS WITH STAFFS OF OFFICE}

After some time, the Whiteman started giving staffs of office to their chiefs. He would go to a clan or kindred group of Tiv and give a staff of office to the chief there, saying that the entire group should revere him and listen to his words and sayings; the person should be like a senior chief. [...]

\section{WAYS THE CHIEF GETS WIVES}

A chief with staff of office has many ways of getting married to many women. If a man begat female children and they grew to adolescence and were beautiful and charming, the children of the chief might see them and tell the chief that soand-so has a beautiful daughter who is ready to be a 'house wife'. If the young 
woman was from the chief's kindred/clan, the issue was settled; the chief had thus already married her! He only had to send for her and as they brought her to him, she became the chief's wife. [...]

\section{FINANCIAL EXTORTION}

The chiefs of those days extorted and confiscated people's money in no small measure. If a man kept a fat bull that looked good, it could well be for the chief, unless the chief did not hear about it. If he heard about it, he would usually send the security guard to tell the owner of the bull, who must bring it to give to the chief, along with additional money for the chief to buy oil, slaughter the bull and eat it. Any animal a person had that was the best was eaten by the chief. [...]

In Tivland, men of wisdom do not get anything; it is fools that are entrusted with responsibility. The Tiv do this for two reasons: in the first instance, they eat a fool's money, then they make him a chief briefly and later strip him of the chieftaincy title for a more knowledgeable person. But they fear giving the title to a man of wisdom, fearing that he may hold it in such a firm grip that they would be unable to strip him of the title, because of his wisdom. But they give to a fool expressly, in order to eat his money completely and take the title from him for another fool and the cycle continues. [...]

\section{NATIVE AUTHORITY POLICEMEN}

When the Whiteman first appointed chiefs with staffs of office, they did not attach security police to them. The chiefs on their own appointed lieutenants to run their errands. When the Whiteman Resident at Katsina-Ala named Dantsofo ${ }^{5}$ came, he appointed security guards called dogari who put on special uniforms. [...] Initially the adugwer were identified with a robe or special blanket, as well as a belt-like cloth that was bound around which was not wide; additionally, the uniform or robe of the messengers consisted of striped robes with a clasped belt. In the past, the Tiv people used to fear dugwer or Native Authority Police a great deal; they addressed them as Zaki dugwer. [...]

\section{THE HEAVY HANDEDNESS OF THE HAUSA}

The Tiv people suffered at the hands of their chiefs because the Hausa workers of the Whiteman increased the suffering of Tiv people. At that time, no Tiv man had been enlisted as an interpreter or messenger. It was only the Hausa who did those jobs. The Whitemen overseeing Tivland in those days did not learn the Tiv

\footnotetext{
${ }^{5}$ Ronald Scott Chapman (born 4 February 1878 in Arabia, and died 5 March 1954 in Middlesex), Assistant Resident in charge of Katsina Ala Division from 1917. This and later identifications are taken from 'Some of the actors in Akiga Sai's History of the Tiv identified by David Dorward' (available with the supplementary materials included with this article online at $<\mathrm{http}: / /$ dx.doi.org/10.1017/S0001972015000613>).
} 
language; they only spoke the Hausa language. They spoke to the Hausa interpreter, who in turn translated and spoke with the Tiv. The Whitemen looked at the Tiv but were unable to speak with them. [...]

\section{A VISIT TO KADUNA}

What helped the chiefs who held staffs of office was their visit to Kaduna. When the chiefs met at Abinsi for their regular meeting, Chafa Fishi ${ }^{6}$ told them that it was the intention of the white people administering Tivland to have Tiv people go to Kaduna to see what the world looked like. Thus, if Tiv people also liked the idea, every chief should prepare to travel to Kaduna with one member of his jury, a security police officer, a messenger, and one wife, since he may want to travel with a wife. They should all do this according to their respective clans/kindred groups. He, Chafa Fishi, would travel along with them by train to see things they had never seen before. They would see different manners of people, they would see the Hausa chief, the Emir, and they might see land that is good for agriculture. According to him, if any one of them wanted to settle there, he would be allowed to do so. All the chiefs agreed that they would go to Kaduna. The Whiteman scheduled a date for the trip and when it was time, all the chiefs, their messengers, security guards and wives got ready for the journey. At the time, the unlawful deeds of three particular chiefs had already been revealed to the Whiteman, Chafa Fishi. The other Whitemen who investigated thoroughly also knew but they never told anybody. When they had all assembled in Makurdi, they boarded a train. My father was among the members of the group travelling to Kaduna, because he was a member of the litigation jury of the chief of the Shitire clan. At the time, the rail line from Makurdi to Kaduna was not yet complete. They entered the train and travelled along, then they disembarked at some point and trekked up to five miles before re-embarking at another point. On arrival at Kaduna, all the senior Whitemen, including all the soldiers, assembled and danced and the Tiv people saw them. The chiefs were also able to recognize certain Whitemen that had earlier on administered Tivland; among them was Maimadubi. ${ }^{7}$ The Tiv people also danced very well. The chief of Zaria [the Emir] donated two hundred mats for the Tiv people to sleep on. He also gave eight cows that they could slaughter and eat. The next day, the chief of Zaria came himself. He came with great dignity; he came with show and splendour; he had three hundred horses. Tiv people saw this and were greatly afraid. They said they themselves were a shame to the chieftaincy; it is only among non-Tiv that there are true chiefs. The chief of Zaria sat with Chafa Fishi and all the Tiv squatted down. The chief then greeted the Tiv people and exchanged pleasantries with them and told them that he was very happy to see them; that they should move round and see his domain, and if they liked it they could settle there, he would not prevent them, he would be very happy. They entered vehicles with the Tiv people and took them around to show them places that were good for farming. They finally came back

\footnotetext{
${ }^{6}$ Captain Gilbert George Feasey (born 26 February 1891 and died June 1976) was a captain in the 2nd Nigerian Regiment in World War I, before entering the Colonial Service as a Political Officer in Nigeria.

${ }^{7}$ Major John Morton Fremantle (born 1876 and died 21 December 1936) earlier served in the Boer War, and retired from the Colonial Service in 1929.
} 
and stood at the entrance of the magistrate's house. The Whiteman asked them if the place was good for them and they praised the place verbally and said it was very good, very good. The Whiteman asked them 'Will you then come here?' The Tiv people said they would come. But behind closed doors, they said, 'Who is the fool who would leave his kindred/clan and go to settle far away in the midst of non-Tiv ethnic groups? We accepted verbally only to make him happy.'

\section{RETURN FROM KADUNA}

The chiefs stayed at Kaduna for three days and on the fourth day, they returned to Makurdi and slept. At dawn, the Whiteman summoned the chiefs and they all assembled in the compound of the chief of Makurdi. The Resident arrived in a vehicle. The Whiteman came to greet the chiefs and told them that they were free to go, they should go in peace, but three chiefs were not free to leave. They said they wanted to discuss things with these three chiefs. When the Tiv people heard this, their hearts beat quickly. Most of them returned secretly to their kindred/clans, except strong-hearted chiefs who slept in Makurdi and went to bid the Whiteman farewell the next day. When all the other chiefs left and only the three in question remained behind, the Whiteman started to interrogate them.

These three were chief Ugba in Ugondo, Moji from Kunav, and Abagi from lower Shangev. The issues people had reported which the Whiteman had heard but did not tell them were these: Ugba ambushed his Ugondo people and collected their money by force, collected their women, and burned some of their villages; Moji was said to have collected many things from his clan/kindred by force, including their women; Abagi was said to have killed his wife at his farm. These were the accusations that members of their own clans/kindred groups had made about them. The Whiteman, Chafa Fishi, presided over their cases and adjudicated. He finished Ugba's case and convicted him, and sent him to Kaduna in exile. Ugba had to leave his clan and that was the punishment the Whiteman gave him. He also finished Moji's case. Moji was not the kind of person who worried the Whiteman by denying allegations against him that were true. The Whiteman investigated the allegations against him and each of the allegations that people made was true, so he accepted. The Whiteman in turn asked him if he expected to pay back the money later on, and he did. He had married women in the manner other chiefs married, as we have already described. His wives were ninety-three in number and he had married them all by force, not paying any dowry. The Whiteman allowed the others to leave by virtue of the adjudication in Abinsi. Moji died as the Whiteman was about to take him to Kaduna; he died on the eve of departure to Kaduna. Some people said he killed himself using poison, but after a thorough investigation of the circumstances of his death, the Whiteman realized it was not poison. He died of cardiac arrest. In Abagi's case, the Whiteman adjudicated at length before it was proved beyond a reasonable doubt that he was at fault. The Whiteman took him to his house at Ishangev, and executed him for murder by hanging him from a fig tree. The fig tree is still there up to this year 1935. That is the end of the story about the trip of the Tiv chiefs to Kaduna. 
After these events happened, Tiv chiefs became more prudent, no longer snatching people's wives by force as they had done before, because they feared being sent to Kaduna. Subsequently, if a chief contravened the law and the Whiteman heard about it, he would ask him if he desired to go and meet Ugba at Kaduna. Such a chief usually said no and would be afraid. Because of this, they no longer collected money from poor people by force, but instead they used other tricks to do so.

$[\ldots]$

\section{MAKURDI}

It is surprising that the town of Makurdi has grown large. I, the person who is writing this book, went to Makurdi in 1912 by boat to see off Ortese Zimmerman and Ortese Guinter and Ortese Dowsen. ${ }^{8}$ At that time Makurdi had no more than five houses. What was present was huts built by the Hausa and the Iharev [a Tiv clan] who had settled close to each other and did fishing. We stopped there by boat and as children we bought food from those Hausa in the very place that is now Makurdi.

Later on, Makurdi became a large town and all kinds of people settled there. One could not say that Makurdi was made up more of one ethnic group or another. They were not all able to understand each other, however. They also practised all sorts of religions. The chief there was Audu dan Afoda, ${ }^{9}$ a man of Yarbawa, who had been granted his authority by the Whiteman. This was during the time of Makondo. ${ }^{10}$ The chief we were most familiar with and heard about was called Audu who was there during the period when the Whiteman was installing the telegraph wires, which took them a long time to complete.

During Audu's rule, the Whiteman turned over the land administration of Iharev to him and both of the clan areas were under his authority; these were Ityôshin and Isherev and the lands of the two Masev clans, Igyenev and Ingohov. Both of these groups were under his authority. They were under him and taxes were collected from them. The collection of tax money was part of his work under the Whiteman and their disputes were also heard by him, and the chief in turn reported to the Whiteman. An amazing thing happened during the time that Audu dan Afoda was chief of Makurdi. It was during his rule in 1913 that the Tiv were in great awe and fear of the Hausa, who taxed the Tiv heavily and continuously, enforcing the rule of the Whiteman. It is not really

\footnotetext{
${ }^{8}$ Carl F. Zimmerman served in the Dutch Reformed Church Mission (DRCM) in Tivland from 1909 until 1912. Reverend Clarence Walter Guinter (born 1877 in Loyalsock, Pennsylvania and died 1941 in Wrightsville, Pennsylvania) was an American member of the Sudan United Mission (SUM). Gilbert Dawson (born 1876 and died 4 November 1959 in Hertfordshire) was also a member of the SUM.

${ }^{9} \mathrm{He}$ was said to be a Yoruba from Bida who had served as cook to William Petch Hewby, who had joined the Royal Niger Company in 1883 and later transferred to the Nigerian Colonial Service.

${ }^{10}$ Hugh Middleton Brice-Smith (born 1884 and died 1967 in Surrey) was appointed Assistant Resident, Katsina Ala, in Northern Nigeria in January 1909. In February 1917, he was transferred to Benin in Southern Nigeria. He served in Zaria and in 1929 was appointed Resident, Southern Provincial Administration. He retired in 1934.
} 
pleasant to talk about how they really extorted much money, but they persisted with this: nothing stood in their way to get the money, nothing obstructed them.

It was during this time that he also became the chief over those Tiv who knew little about the Uke [foreign but particularly Hausa] antecedents. The Whiteman gave them authority over them as they travelled very little to these lands. If he had been like the other Hausas who work for the Whiteman in Tivland that we know, they extorted from the Tiv a great deal. But he was not like that.

The Uke worked for the Whiteman among the Tiv, and they understood the ways of the Whiteman and thus reaped great benefit from them while collecting taxes. Yet he [Audu] did not take things from the Tiv by force, he was too clever for that. $\mathrm{He}$ befriended the Tiv and they liked him. When the Tiv visited him to pay homage with gifts, he reciprocated. He would not let them go back empty handed. So when the Tiv under his rule paid taxes, and the Whiteman gave money in return for the Tiv through him, he did not extort the Tiv (by way of blowing on a chief's coal and swallowing the smoke) in a way they would notice like the other Uke. This in turn pleased the Tiv under them, who in turn even wrote hymns in his praise, so the town of Makurdi and the people of Iharev called out, Geri-Audu, and at times even called Makurdi by the name of Audu.

$[\ldots]$

Makurdi began to grow during the period of preparation for the installation of the train tracks. The tracks entered Masev, passed through it and emerged into Iharev, crossed the big river at Makurdi, then ran on into the lands of the Hausa. The train track in the Tiv area was called Adôgôn. The meaning of adôgôn in the Tiv language is to be bent, huren, this way and that. It was at the time of its construction that most of the white colonial administrators, white road engineers and white businessmen came to settle at Makurdi as well as their leader. When lots of people gathered at Makurdi, something happened. The price of food increased greatly. The coming of the railway was really the beginning of the expansion and development of Makurdi and provided the impetus for its growth.

The most noteworthy aspect of the development and popularity of Makurdi was the bridge that the Whitemen constructed across the great river; nothing else was as amazing to the Tiv as the Whiteman's ability to make a bridge that crossed the large river. This bridge was constructed in a period of five years. Many Whitemen worked on it, as well as many Tiv who were involved in the construction as labourers. But there were also men from Igbo land and Akporo or Idoma, along with other people from different ethnic groups who gathered to do all the work.

As the Whitemen began to work on the bridge, the Tiv said, 'Never, never! The Whitemen do not have the ability to construct a bridge across such a huge expanse of river.' As the construction went forward and many laboured on the project, many local workers died, though not many Whitemen died. Of those who did die, they did so when huge holes were dug in the bottom of the riverbed, under the water - that was what killed the most men.

During the construction period, many people gathered in and around Makurdi to bring this or that for sale and to get money from the labourers this way. White traders came as well and settled in the town during the construction of the bridge at Makurdi. Everyone who engaged in one kind of selling and trade or another all were pleased. Such growth attracted many women of easy virtue as well who gathered there, along with thieves. So the Whiteman's police force had plenty to do to keep things in order, and the Whiteman's court was a busy place and did 
not lack for cases to try. So they were all very busy during this period. All those employed by the government were also fed up with these incidents during the construction period.

\section{THE BRIDGE OPENING}

After the work on the bridge had been completed, the Whitemen who were governing the land called the chiefs of the Tiv as well as those of Idoma, along with their councillors, judges and elders, and even all those who had been involved as workers on the bridge project to come to witness their Governor introducing the railway and the train which passed from one part of the land to the other. The opening date was May $24^{\text {th }} 1933$. The Governor who came to officiate at the bridge opening was Gomna Kamaru. ${ }^{11}$ That was a great day! Many of the Tiv people and others from Idoma met in Makurdi, and it was a time that the people will not forget. The Tiv were very impressed and talked among themselves and discussed many things, such as: the Whiteman is ready to destroy them all, he has called them to this gathering to put all of them on the train and take them across the bridge, the bridge will collapse once they are on it and they will all perish! Others said that perhaps the Whiteman would gather all of them and take them on the train to Kaduna into exile. So the Whiteman prepared a feast for the chiefs and killed many cows for the people to eat, yet they ate with sadness not knowing the full intention of the gathering by the Whiteman. Others however said, if the Whiteman had bad intentions for this gathering, he would not have wasted all the slaughtered animals for a feast. Others said further that the Whiteman couldn't care less about the slaughtered animals. That even when a man kills another and is to be hanged, yet the Whiteman will slaughter animals and ask the condemned man to feast on one before his death: this feast was therefore their last meal from the Whiteman. The chiefs all became fainthearted. The Whiteman also gave the chiefs an honorarium for food and instead most of them were using this to purchase types of akômbo [cults] from the Hausa.

On May $24^{\text {th }}, 1933$, the Governor of the land came in the afternoon. All the chiefs gathered in their splendour at Makurdi where the bridge crossed from one side to the other of the river. At the appearance of the Governor, the chiefs all wetted themselves in fear of what was to befall them by the hands of the Governor, some wetted themselves five times at a go in fear. Many of the Whitemen crossed the bridge to the other side and waited for the Governor to cross over.

The people who were responsible for looking after the crowds were the 'udansanda' [policemen with batons]; the Whiteman in charge of them had them standing all in order according to rank. When the Governor arrived, many bugles were sounded and the crowds began to cheer wildly and clap their hands. The Governor waved, [and] returned their greetings with praise for all the people. Many praised the beautiful colour parade by the policemen on that day and the Whiteman in charge of the police.

\footnotetext{
${ }^{11}$ Sir Donald Charles Cameron (1872-1948), Governor of Tanganyika (1925-31) and of Nigeria (1931-35).
} 
He arrived by crossing the bridge while standing on the train, which was moving slowly. The Tiv began to eulogize the Whiteman with songs in unison and to cheer loudly. The Governor came out and, seeing the large crowd, crossed into the station house at Makurdi and entered a car to take him to the barki [the barracks]. When he got there, all the chiefs were gathered in the courtyard. They all passed before the Governor according to rank, a 'durbar':12 the local chiefs first, then their judges, then later the police force and soldiers. Following these were those not under orders and all gathered there.

The white people had arranged chairs near the entrance gate where they had constructed things. Then they all sat down except the Governor, who stood up above them all and looked over the people.

\section{THE SPEECH OF THE GOVERNOR (SIR DONALD CAMERON)}

The Governor acknowledged the Tiv and they called back their greetings. He said that the King of the Whitemen had sent him to this country and so he was like the king himself over this land. He had also appointed other Whitemen there who were in the land helping to care for it, keeping it well maintained and in good order. Their attitude to them was one of care and seeking what was good and peaceful for them. Thus it was good and right for the Tiv people in turn to offer their help and assistance in keeping their land in good order. If there were things that confused or bothered them, they should come to their respective Whiteman. That Whiteman would then ensure that all was clarified and made well. Similarly, if the Whiteman did something that appeared to be confusing or inappropriate for the Tiv, they should not hide their concern, or shy away, but approach the Whitemen openly with their concerns for the land. He, the Governor, would respond to the concerns presented to him. The Whitemen would look into it, and if it were a matter for the common good, he would gladly accept and do what the Tiv ask. However, if the concerns were such as to bring the land backwards, that would become a bone of contention. The Governor reiterated all the good intentions of his administration over Tivland.

After these deliberations, they came and ate together at noon with the great Whiteman of Aro [the rail network construction] that they called Mata Remsi. The Tiv then returned to Makurdi town, and the Governor got back on the train and left at dusk.

\section{ENTERING INTO DZWA [LARGE CINEMA HALL]}

After all of this was completed, the Whiteman called on all the chiefs present and handed them four tickets or documents of authority. He pointed out a large building at the bank of the river near the river crossing. All the chiefs who had the papers were to go into the structure one at a time with three guests at night to

\footnotetext{
${ }^{12}$ Durbar was a term commonly used by British Colonial Officers who had served in India. It was derived from Hindi and Persian for a ruler's court. Commonly, it was a parade that passed before those who ruled.
} 
enter into the building. (This ticket was like an invitation paper so that no random or uninvited guests would enter the building.)

So the chiefs received their tickets but did not understand the meaning of these. They returned to their villages and misinformed the voice of the Whiteman to their people. They also misinterpreted what the tickets were for and then became afraid and disheartened. They said that since they had escaped going to Kaduna, the Whiteman's intention was to lock them up in the big house and destroy them once they entered the big house which they called 'jegezwa' [gaping maw]. There would be no escape for them this time. As soon as they would enter, the door of the $d z w a$ would be shut and they would be burnt to death. The chiefs panicked further and said goodbyes to their wives, some saying: 'My wife as I leave you today, just wait for the news, as soon as we are burnt and dead, go and tell my son that, even as I was crying, I knew it was not in vain as I have told him all my secrets before my death. Let him fulfil my wishes.' Some would say to their wives, 'I can never leave you all by yourself, in death we shall go together,' and some chiefs just developed an unexpected akesagh illness.

When night came, the Whiteman displayed fireworks of different colours which appeared and were seen by many in the sky. They would fly up in the sky, explode and display various brightly shining lights which were green, white and red. The town came to a standstill and silence was everywhere and the people became distressed and in fear. As soon as the fireworks display finished, we, the invited guests, entered into the building's gate and the door was then shut.

We were shocked at the 'photos' we saw which we had never seen in our lives. Other photos seen previously were still images. These were not still photos but such that when one walked and talked you could see their lips move but not hear their voices. What was in the film showed a Whiteman who ran over another white female in his car and immediately came down and took her and put [her] in the car and drove away; another Whiteman fought another, beat him up and the loser ran away to his house; another Whiteman rode on a big white horse galloping, the horse made him fall down, he got up and climbed on it again and rode away. All of these were happening in the 'movie'; we were so baffled and surprised that until today, the Tiv people still talk about this 'moving images' of a photo.

This was the biggest thing that happened in Makurdi on that day. The opening of the bridge also happened in one day. At the break of day on May $24^{\text {th }} 1933$, after the bridge was declared open, the chiefs were allowed to go to their clans.

As the Tiv dispersed and went back to their clans, Gbatar, the chief with staff of authority of Nôngov from Ndzôrov, gave Kokoiwen Adugu, the chief with staff of Mbayiôn, a wife which he brought to Gundu market at Nôngov; as Tiv saw that, there was much gossip on the day. They said: 'As the chiefs gathered at Makurdi for the bridge opening, Jato Aka requested the Governor to allow the Tiv to woo or capture wives so that Tiv land will be good once more. So, the Governor agreed to the request: can't you see, Kokoiwen, the chief with a staff captured a wife for free, therefore it must now be acceptable for all.'

Then the Tiv erroneously started capturing women again; the Whiteman had to put a lot of them into prison, which made them calm down; they only did it secretly just as they do to this day.

That is all the information about Makurdi. 